\title{
IMPLEMENTASI ASAS-ASAS UMUM HUKUM KEBENDAAN DALAM UNDANG-UNDANG NOMOR 42 TAHUN 1999 TENTANG JAMINAN FIDUSIA
}

\author{
Vivi Lia Falini Tanjung \\ Program Magister Kenotariatan \\ Universitas Muhammadiyah Sumatera Utara \\ E-mail: tanjungn10@gmail.com
}

\begin{abstract}
The fiduciary guarantee agency is very helpful for the smoothness of business managed by the debtor, because the goods used as security for the repayment of its debts remains in its power. Fiduciary guarantee is a part of the material law, so the principles of material law must be adopted in the legal rules of the fiduciary guarantee agency, which is currently regulated in Act No. $42 / 1999$, but this law needs to be revised, especially in relation to the registration of fiduciary collateral, fiduciary execution and the possibility of whether or not fiduciary assets should be used as a fiduciary guarantee again.
\end{abstract}

\section{Kata Kunci: Fidusia, Hukum Kebendaan, Jaminan.}

\section{A. Latar Belakang}

Dalam pelaksanaan perjanjian pinjam meminjam uang (kredit), maka lembaga jaminan mempunyai fungsi yang penting bagi pelunasan hutang si debitor. Ada berbagai bentuk lembaga jaminan yang terkait dengan perjanjian kredit yang pernah dikenal dalam praktik, antara lain: hipotik dan creditverband (sekarang menjadi hak tanggungan), gadai dan fidusia. Aturan hukum tentang lembaga jaminan ini tentunya ditujukan untuk memberikan kepastian hukum bagi si pemberi modal (kreditor) agar sejumlah uang yang telah dipinjamkannya kepada si peminjam (debitor) dapat dikembalikan kepadanya, dan jika debitor tidak dapat mengembalikan hutang, maka benda yang dijaminkanlah sebagai penggantinya.

Pemberian pinjaman modal dari lembaga keuangan (baik bank maupun non bank) mensyaratkan adanya suatu jaminan yang harus dipenuhi oleh para pencari modal, jika ia ingin mendapatkan pinjaman modal (kredit), baik untuk jangka panjang maupun jangka pendek. Bagi pihak debitor bentuk jaminan yang 
baik adalah bentuk jaminan yang tidak akan melumpuhkan kegiatan usahanya sehari-hari, sedangkan bagi kreditor jaminan yang baik adalah jaminan yang dapat memberikan rasa aman dan kepastian hukum bahwa kredit yang diberikan dapat diperoleh kembali tepat pada waktunya.

Salah satu lembaga jaminan yang dikenal dalam sistem hukum jaminan di Indonesia adalah lembaga jaminan fidusia. Lembaga jaminan fidusia sangat membantu bagi kelancaran usaha yang dikelola debitor, karena barang yang dijadikan jaminan bagi pelunasan hutangnya tetap berada dalam kekuasaannya. Hal ini diperbolehkan karena memang jaminan fidusia berarti penyerahan hak milik atas dasar kepercayaan yang memberikan kedudukan kepada debitor untuk tetap menguasai barang jaminan, walaupun hanya sebagai peminjam pakai untuk sementara waktu atau tidak lagi sebagai pemilik.

Jenis barang yang dapat dijadikan jaminan dalam fidusia sama halnya dengan jaminan dalam gadai, yaitu sama-sama barang bergerak, tetapi kalau dibandingkan dengan ketentuan tentang gadai yang terdapat dalam Pasal 1152 KUH Perdata yang disyaratkan bahwa barang jaminan diserahkan secara fisik kepada pemberi kredit (kreditor), maka dalam jaminan fidusia barangnya tetap berada pada penerima kredit (debitor). Selain itu, berdasarkan ketentuan Pasal 1152 KUH Perdata, jika barang jaminan tetap dibiarkan dikuasai debitor maka jaminan tersebut tidak sah.

Sejak tahun 1999, lembaga jaminan fidusia telah diakui eksistensinya melalui Undang-undang Nomor 42 Tahun 1999 tentang Jaminan Fidusia (selanjutnya disingkat UU No. 42 Tahun 1999), yang telah diundangkan pada tanggal 30 September 1999. Berdasarkan undang-undang ini dapat diketahui bahwa jaminan fidusia merupakan jaminan atas benda bergerak yang berwujud maupun tidak berwujud atau yang tidak dapat dibebani hak tanggungan menurut Undang-undang Nomor 4 Tahun 1996 tentang Hak Tanggungan (selanjutnya disingkat UU No. 4 Tahun 1996) yang dimiliki oleh penerima fidusia yang terdaftar di Kantor Pendaftaran Fidusia, yaitu sebagai agunan bagi pelunasan utang tertentu dan yang mempunyai hak untuk didahulukan daripada para kreditor lainnya, sedangkan fidusia adalah pengalihan hak kepemilikan suatu benda atas 
dasar kepercayaan dengan ketentuan bahwa benda yang hak kepemilikannya dialihkan tersebut tetap dalam penguasaan pemilik benda.

Sebenarnya lembaga jaminan fidusia ini sudah sejak dulu dipraktikkan oleh pelaku-pelaku bisnis, tepatnya sejak terjadi krisis dalam bidang hukum jaminan pada pertengahan sampai dengan akhir abad 19. Pada waktu itu terjadi pertentangan berbagai kepentingan yang ditandai dengan permasalahan yang dihadapi oleh perusahaan-perusahaan pertanian yang melanda negara Belanda, bahkan seluruh negara-negara di Eropa. Kondisi ini telah menyebabkan munculnya lembaga jaminan fidusia yang keberadaannya masih didasarkan pada yurisprudensi (Auditmepost.blogspot.com., http://auditme-post.blogspot.com).

Sebagai salah satu jajahan negara Belanda, Indonesia pada waktu itu juga merasakan imbasnya. Untuk mengatasi masalah ini, lahirlah peraturan tentang Ikatan Panen atau Oogstverband (Staatsblad 1886 Nomor 57). Peraturan ini mengatur mengenai peminjaman uang, yang diberikan dengan jaminan panenan yang akan diperoleh dari suatu perkebunan. Dengan adanya peraturan ini maka dimungkinkan untuk mengadakan jaminan atas barang-barang bergerak atau setidak-tidaknya kemudian menjadi barang bergerak, sedangkan barang-barang itu tetap berada dalam kekuasaan debitor. Seperti halnya di Belanda, keberadaan fidusia di Indonesia, juga diakui oleh yurisprudensi berdasarkan keputusan Hooggerechtshof (HGH) tanggal 18 Agustus 1932 (Auditmepost.blogspot.com., http://auditme-post.blogspot.com).

Dalam perjalanannya, fidusia telah mengalami perkembangan yang cukup berarti. Perkembangan itu misalnya menyangkut kedudukan para pihak (kreditor dan debitor), termasuk hubungannya dengan pihak ketiga dan mengenai objek yang dapat difidusiakan. Mengenai objek fidusia ini, baik Hoge Raad Belanda maupun Mahkamah Agung di Indonesia secara konsekuen berpendapat bahwa fidusia hanya dapat dilakukan atas barang-barang bergerak. Namun dalam praktiknya, orang sudah menggunakan jaminan fidusia terhadap barang-barang tidak bergerak.

Terkait dengan kedudukan para pihak dalam pelaksanaan fidusia, termasuk pula terhadap objek fidusia yang dalam praktiknya semakin kabur, yang tentunya 
juga belum dapat menjamin adanya kepastian hukum, maka pemerintah memandang perlu untuk mengeluarkan undang-undang tentang fidusia. Jaminan fidusia ini sebenarnya merupakan salah satu jenis hak kebendaan (sama halnya seperti hipotik dan gadai), tetapi tidak ada pengaturannya ditemui dalam KUH Perdata, sehingga perlu dibuat aturannya secara khusus guna memberikan kepastian hukum bagi para pihak yang mengadakannya. Oleh sebab itu, dapat dikatakan bahwa jaminan fidusia merupakan bagian dari lapangan hukum kebendaan sebagaimana yang terdapat dalam Buku II KUH Perdata dan oleh sebab itu pula bahwa asas yang berlaku umum dalam hukum kebendaan (Buku II KUH Perdata) berlaku pula bagi jaminan fidusia.

Berhubung bahwa jaminan fidusia merupakan bagian dari hukum kebendaan, maka sudah semestinya UU No. 42 Tahun 1999, menganut asas umum hukum kebendaan yang terdapat dalam Buku II KUH Perdata. Dengan kata lain bahwa asas-asas hukum kebendaan yang terdapat dalam UU No. 42 Tahun 1999, harus disesuaikan dengan asas-asas hukum kebendaan yang terdapat dalam Buku II KUH Perdata. Sesuai hal tersebut, maka artikel ini pada dasarnya untuk mendeskripsikan dan menganalis kesesuaian penerapan asas-asas hukum kebendaan dalam UU No. 42 Tahun 1999, sehingga yang perlu ditelaah adalah tentang implementasi asas-asas umum hukum kebendaan dalam peraturan tentang jaminan fidusia.

\section{B. Hakikat Fidusia dan Jaminan Fidusia}

Fidusia menurut asal katanya berasal dari kata "fides", yang berarti kepercayaan. Sesuai dengan arti kata ini maka hubungan hukum antara debitor dan kreditor merupakan hubungan hukum yang berdasarkan pada kepercayaan (Gunawan Widjaya dan Ahmad Yani, 2001: 113). Fidusia merupakan istilah yang sudah lama dikenal dalam Bahasa Indonesia dan sejak tahun 1999 istilah fidusia telah digunakan dalam UU No. 42 Tahun 1999. Dengan demikian, istilah fidusia sudah merupakan istilah resmi dalam dunia hukum bisnis di Indonesia.

Menurut Sri Soedewi Masjchoen Sofwan (1997: 27), dikatakan bahwa adakalanya dalam Bahasa Indonesia terhadap kata fidusia ini disebut juga dengan 
istilah "Penyerahan Hak Milik Secara Kepercayaan", sedangkan dalam literatur Belanda, fidusia dikenal juga dalam istilah-istilah sebagai berikut:

1. Zekerheids eigendom (hak milik sebagai jaminan).

2. Bezitloos zekerheidsrecht (jaminan tanpa menguasai).

3. Verruimd pand begrip (gadai yang diperluas).

4. Eigendom overdracht tot zekerheid (penyerahan hak milik secara jaminan).

5. Bezitloos pand (gadai tanpa penguasaan).

6. Een verkapt pand recht (gadai berselubung).

7. Uitbaouw pand (gadai yang diperluas).

Dalam Pasal 1 UU No. 42 Tahun 1999 dijelaskan bahwa fidusia adalah pengalihan hak kepemilikan suatu benda atas dasar kepercayaan dengan ketentuan bahwa benda yang hak kepemilikannya dialihkan tetap dalam penguasaan pemilik benda, sedangkan jaminan fidusia adalah hak jaminan atas benda bergerak baik yang berwujud maupun yang tidak berwujud dan benda tidak bergerak khususnya bangunan yang tidak dapat dibebani hak tanggungan sebagaimana dimaksud dalam UU No. 4 Tahun 1996 yang tetap berada dalam penguasaan pemberi fidusia, sebagai agunan pelunasan utang tertentu, yang memberikan kedudukan yang diutamakan kepada penerima fidusia terhadap kreditor lainnya.

Berdasarkan definisi yang diberikan oleh UU No. 42 Tahun 1999 tersebut, jelas terlihat bahwa fidusia dibedakan dengan jaminan fidusia. Fidusia adalah suatu proses pengalihan hak kepemilikan dan jaminan fidusia adalah jaminan yang diberikan dalam bentuk fidusia. Pranata (lembaga) jaminan fidusia yang diatur dalam UU No. 42 Tahun 1999 adalah pranata jaminan fidusia dalam bentuk fiducia cum creditore contracta, yaitu jaminan yang dibebankan atas suatu benda bergerak secara fidusia sebagai bagian yang disebut pemberian jaminan dengan kepercayaan. Jaminan fidusia lebih dikedepankan dalam UU No. 42 Tahun 1999 daripada pengertian fidusia itu sendiri. Hal ini didasarkan pada maksud dari perjanjian fidusia yang dibuat berdasarkan UU No. 42 Tahun 1999, yang pada dasarnya adalah proses hubungan hukum dalam dunia usaha yang bertumpu pada unsur saling membantu dan itikad baik dari masing-masing pihak. Faktanya dapat terlihat dari konsepsi fidusia dan jaminan dalam perjanjian fidusia itu sendiri yang 
sejak awal sampai dengan perkembangannya sekarang bercirikan tidak adanya penguasaan benda jaminan oleh penerima fidusia, padahal terhadap benda bergerak keadaan tersebut sangat berisiko (Gunawan Widjaya dan Ahmad Yani, 2001: 123-131).

Dalam terminologi lainnya (Bahasa Belanda) istilah fidusia yang paling sering digunakan adalah Fiduciare Eigendonts Overdracht (FEO), sedangkan dalam Bahasa Inggris secara lengkap sering disebut dengan istilah Fiduciary Transfer of Ownership (Munir Fuady, 2000: 3), sedangkan di Indonesia, penggunaan istilah penyerahan hak milik secara kepercayaan sebagaimana disebutkan sebelumnya adalah lebih didasarkan pada konsepsi dalam praktiknya.

Menurut J. Satrio (2002: 160-175), dikatakan bahwa berbagai istilah dan pengertian yang diberikan, dapat dikatakan bahwa unsur-unsur dalam fidusia terdiri dari:

1. Unsur secara kepercayaan dari sudut pemberi fidusia. Unsur ini mempunyai peranan penting dalam fidusia dan hal ini juga tampak dari penyebutan unsur di dalam UU No. 42 Tahun 1999. Arti kepercayaan selama ini dalam praktik, yaitu:

a. Debitor pemberi jaminan percaya, bahwa benda fidusia yang diserahkan olehnya tidak akan benar-benar dimiliki oleh kreditor penerima jaminan tetapi hanya sebagai jaminan saja.

b. Debitor pemberi jaminan percaya bahwa kreditor terhadap benda jaminan hanya akan menggunakan kewenangan yang diperolehnya sekedar untuk melindungi kepentingan sebagai kreditor saja.

c. Debitor pemberi jaminan percaya bahwa hak milik atas benda jaminan akan kembali kepada debitor pemberi jaminan kalau hutang debitor untuk mana diberikan jaminan fidusia dilunasi.

2. Unsur kepercayaan dari sudut penerima fidusia, berarti bahwa penerima fidusia percaya bahwa barang yang menjadi jaminan akan dipelihara/dirawat oleh pemberi fidusia.

3. Unsur tetap dalam penguasaan pemilik benda.

4. Kesan ke luar bahwa benda jaminan tetap berada di tangan pemberi fidusia. 
5. Merupakan hak mendahului (preferen) bagi pelunasan hutang-hutang lainnya.

6. Bersifat accessoir, maksudnya hanya merupakan perjanjian ikutan (tambahan) yang tidak akan ada tanpa adanya perjanjian pokok.

Purwahid Patrik dan Kashadi (2001: 36-37), mengatakan bahwa, seperti halnya dengan hak tanggungan, lembaga jaminan fidusia mempunyai ciri-ciri, sebagai berikut:

1. Memberikan kedudukan yang mendahulu kepada kreditor penerima fidusia terhadap kreditor lainnya (Pasal 27 UU No. 42 Tahun 1999).

2. Droit de suite, maksudnya bahwa jaminan fidusia selalu mengikuti obyek yang dijaminkan di tangan siapapun obyek itu berada (Pasal 20 UU No. 42 Tahun 1999).

3. Memenuhi asas spesialitas dan publisitas sehingga mengikat pihak ketiga dan memberikan jaminan kepastian hukum kepada pihak-pihak yang berkepentingan (Pasal 6 dan Pasal 11 UU No. 42 Tahun 1999).

4. Mudah dan pasti pelaksanaan eksekusinya (Pasal 29 UU No. 42 Tahun 1999).

Berdasarkan Pasal 4 UU No. 42 Tahun 1999 secara tegas dinyatakan bahwa jaminan fidusia merupakan perjanjian "accesoir" dari suatu perjanjian pokok yang menimbulkan kewajiban bagi para pihak untuk memenuhi suatu prestasi yang berupa memberikan sesuatu, berbuat sesuatu atau tidak berbuat sesuatu yang dapat dinilai dengan uang. Purwahid Patrik dan Kashadi (2001: 125), juga mengatakan bahwa sebagai perjanjian accesoir, maka perjanjian jaminan fidusia memiliki sifat sebagai berikut:

1. Sifat ketergantungan terhadap perjanjian pokok.

2. Keabsahannya semata ditentukan oleh sah tidaknya perjanjian pokok.

3. Sebagai perjanjian bersyarat maka hanya dapat dilaksanakan jika ketentuan yang disyaratkan dalam perjanjian pokoknya telah atau tidak dipenuhi.

Apabila pemberi fidusia cidera janji, maka menurut Pasal 29 UU No. 42 Tahun 1999, benda yang menjadi obyek jaminan fidusia dapat dilakukan eksekusi dengan cara:

1. Pelaksanaan titel eksekutorial sebagaimana dimaksud dalam Pasal 15 ayat (2) oleh penerima fidusia. 
2. Penjualan benda yang menjadi obyek jaminan fidusia atas kekuasaan penerima fidusia sendiri melalui pelelangan umum.

3. Penjualan di bawah tangan yang dilakukan berdasarkan kesepakatan antara pemberi fidusia dengan penerima fidusia, jika dengan demikian dapat diperoleh harga tertinggi yang menguntungkan para pihak.

Dalam rangka pelaksanaan eksekusi jaminan fidusia, pemberi fidusia wajib menyerahkan benda yang menjadi obyek jaminan fidusia. Apabila pemberi fidusia tidak menyerahkan pada waktu eksekusi dilaksanakan, penerima fidusia berhak mengambil benda yang menjadi obyek jaminan fidusia tersebut dan kalau perlu dapat meminta bantuan pihak yang berwenang. Dalam hal hasil eksekusi melebihi nilai penjaminan, penerima fidusia wajib mengembalikan kelebihan tersebut kepada pemberi fidusia, tetapi apabila hasil eksekusi tidak mencukupi untuk pelunasan hutang, pemberi fidusia (debitor ) tetap bertanggung jawab atas hutang yang belum dibayar yaitu berdasarkan perjanjian hutang piutang biasa tanpa jaminan fidusia.

\section{Asas-asas dalam Hukum Kebendaan}

Mariam Darus Badrulzaman seperti yang dimuat dalam (Kuliahade's Blog, http://kuliahade.wordpress.com), menjelaskan bahwa dalam sistem hukum benda terdapat 10 (sepuluh) asas umum yang sifatnya relatif konkrit, yaitu:

1. Asas sistem tertutup, artinya bahwa hak-hak atas benda bersifat limitatif, terbatas hanya pada yang diatur undang-undang. Di luar itu dengan perjanjian tidak diperkenankan menciptakan hak-hak yang baru.

2. Asas hak mengikuti benda/zaaksgevolg, droit de suite, yaitu hak kebendaan selalu mengikuti bendanya di mana dan dalam tangan siapapun benda itu berada. Asas ini berasal dari hukum romawi yang membedakan hukum harta kekayaan (vermogensrecht) dalam hak kebendaan (zaakkelijkrecht) dan hak perseorangan (persoonlijkrecht).

3. Asas publisitas, yaitu dengan adanya publisitas (openbaarheid) adalah pengumuman kepada masyarakat mengenai status pemilikan. Pengumuman hak atas benda tetap/tanah terjadi melalui pendaftaran dalam buku tanah/ 
register yang disediakan untuk itu sedangkan pengumuman benda bergerak terjadi melalui penguasaan nyata benda itu.

4. Asas spesialitas, bahwa berdasarkan asas ini dalam lembaga hak kepemilikan hak atas tanah secara individual harus ditunjukkan dengan jelas ujud, batas, letak, luas tanah. Asas ini terdapat pada hak milik, hak guna usaha, hak guna bangunan atas benda tetap.

5. Asas totalitas, maksudnya bahwa hak pemilikan hanya dapat diletakkan terhadap obyeknya secara totalitas dengan perkataan lain hak itu tidak dapat diletakkan hanya untuk bagian-bagian benda. Misalnya: pemilik sebuah bangunan dengan sendirinya adalah pemilik kosen, jendela, pintu dan jendela bangunan tersebut. Tidak mungkin bagian-bagian tersebut kepunyaan orang lain.

6. Asas accessie/asas pelekatan, maksudnya bahwa suatu benda biasanya terdiri atas bagian-bagian yang melekat menjadi satu dengan benda pokok seperti hubungan antara bangunan dengan genteng, kosen, pintu dan jendela. Asas ini menyelesaikan masalah status dari benda pelengkap (accessoir) yang melekat pada benda pokok (principal). Menurut asas ini pemilik benda pokok dengan sendirinya merupakan pemilik dari benda pelengkap. Dengan perkataan lain bahwa status hukum benda pelengkap mengikuti status hukum benda pokok. Benda pelengkap itu terdiri dari bagian (bestanddeed) benda tambahan (bijzaak) dan benda penolong (hulpzaak).

7. Asas pemisahan horizontal, bahwa dalam KUH Perdata dianut asas pelekatan sedang UUPA menganut asas horizontal yang diambil alih dari hukum Adat. Jual beli hak atas tanah tidak dengan sendirinya meliputi bangunan dan tanaman yang terdapat di atasnya. Jika bangunan dan tanaman akan mengikuti jual beli hak atas tanah harus dinyatakan secara tegas dalam akta jual beli. Pemerintah menganut asas vertikal untuk tanah yang sudah memiliki sertifikat untuk tanah yang belum bersertifikat menganut asas horizontal.

8. Asas dapat diserahkan, bahwa hak pemilikan mengandung wewenang untuk menyerahkan benda. Untuk membahas tentang penyerahan sesuatu benda 
maka harus diketahui tentang macam-macam benda yang dikenal dalam Buku II KUH Perdata.

9. Asas perlindungan. Asas ini dapat dibedakan dalam dua jenis yaitu perlindungan untuk golongan ekonomi lemah dan kepada pihak yang beritikad baik (to goeder trouw), walaupun pihak yang menyerahkannya tidak wenang berhak (beschikkingsonbevoegd). Hal ini dapat dilihat dalam Pasal 1977 KUH Perdata.

10. Asas absolute (hukum pemaksa), bahwa berdasarkan asas ini hak kebendaan itu wajib dihormati atau ditaati oleh setiap orang yang berbeda dengan hak relatif.

\section{Asas-asas Hukum Kebendaan dalam Jaminan Fidusia}

Istilah jaminan merupakan terjemahan dari Bahasa Belanda yaitu "zekerheid" atau "cautie", yang secara umum merupakan cara-cara kreditor menjamin dipenuhinya tagihannya, selain itu juga merupakan pertanggungjawaban debitor terhadap barang-barangnya. Selain istilah jaminan, dikenal juga istilah atau kata-kata agunan. Pada dasarnya, pemakaian istilah jaminan dan agunan adalah sama, tetapi dalam praktik perbankan penggunaan istilah ini dibedakan. Istilah jaminan mengandung arti sebagai kepercayaan/keyakinan dari bank atas kemampuan atau kesanggupan debitor untuk melaksanakan kewajibannya, sedangkan agunan diartikan sebagai barang/benda yang dijadikan jaminan untuk melunasi utang nasabah debitor.

Pengertian jaminan terdapat dalam S.K. Direksi Bank Indonesia Nomor: 23/69/KEP/DIR tanggal 28 Pebruari 1991, yaitu suatu keyakinan kreditor bank atas kesanggupan debitor untuk melunasi kredit sesuai dengan yang diperjanjikan. Sedangkan pengertian agunan diatur dalam Pasal 1 angka 23 UU No. 10 Tahun 1998 (UU Perbankan), yaitu jaminan pokok yang diserahkan debitor dalam rangka pemberian fasilitas kredit atau pembiayaan berdasarkan prinsip syari'ah.

Dalam perjanjian pinjam meminjam uang (perjanjian kredit), maka secara umum kegunaan dari jaminan, adalah untuk: 
1. Memberikan hak dan kekuasaan kepada bank/kreditor untuk mendapatkan pelunasan agunan, apabila debitor melakukan cidera janji.

2. Menjamin agar debitor berperan serta dalam transaksi untuk membiayai usahanya, sehingga kemungkinan untuk meninggalkan usahanya/proyeknya, dengan merugikan diri sendiri, dapat dicegah.

3. Memberikan dorongan kepada debitor untuk memenuhi janjinya, misalnya dalam pembayaran angsuran pokok kredit setiap bulannya.

Sedangkan syarat-syarat benda yang dijadikan jaminan adalah:

1. Secara mudah dapat membantu diperolehnya kredit itu, oleh pihak yang memerlukannya.

2. Tidak melemahkan potensi/kekuatan si pencari kredit untuk melakukan dan meneruskan usahanya.

3. Memberikan informasi kepada debitor, bahwa barang jaminan setiap waktu dapat di eksekusi, bahkan diuangkan untuk melunasi utang si penerima (nasabah debitor).

Dalam praktiknya ada dikenal beberapa jenis jaminan, yang dapat digolongkan berdasarkan sifatnya, objeknya serta cara terjadinya. Adapun penggolongan masing-masing dari jaminan tersebut, dapat dijelaskan sebagai berikut:

1. Penggolongan jaminan berdasarkan sifatnya, terdiri dari:

a. Jaminan yang bersifat umum, yaitu jaminan yang diberikan bagi kepentingan semua kreditor dan menyangkut semua harta benda milik debitor, sebagaimana yang diatur dalam Pasal 1131 KUH Perdata. Benda yang dijaminkan disini adalah segala harta/hak kebendaan si berhutang, baik yang bergerak maupun yang tidak bergerak, baik yang sudah ada maupun yang baru akan ada di masa mendatang, menjadi tanggungan untuk semua perikatan perorangan.

b. Jaminan yang bersifat khusus, yaitu jaminan yang diberikan dengan penunjukan atau penyerahan atas suatu benda/barang tertentu secara khusus, sebagai jaminan untuk melunasi utang/kewajiban debitor, baik secara kebendaan maupun perorangan, yang hanya berlaku bagi kreditor tertentu saja. 
c. Jaminan yang bersifat kebendaan dan perorangan. Jaminan yang bersifat kebendaan adalah jaminan yang berupa hak mutlak atas suatu benda. Penggolongan jaminan bersifat kebendaan dilembagakan dalam bentuk hipotik, hak tanggungan, gadai (pand) dan fidusia, sedangkan jaminan yang bersifat perorangan, dapat berupa borgtogh (personal guarantee) oleh pihak ketiga secara perorangan dan jaminan perusahaan oleh suatu badan usaha yang berbadan hukum.

2. Penggolongan jaminan berdasarkan objeknya, terdiri dari:

a. Jaminan dalam bentuk benda bergerak. Dikatakan benda bergerak, karena sifatnya yang bergerak dan dapat dipindahkan atau dalam UU dinyatakan sebagai benda bergerak, misalnya pengikatan hak terhadap benda bergerak. Jaminan dalam bentuk benda bergerak dibedakan atas benda bergerak yang berwujud, pengikatanya dengan gadai (pand) dan fidusia, serta benda bergerak yang tidak berwujud, yang pengikatannya dengan gadai (pand), cessie dan account revecieble.

b. Jaminan dalam bentuk benda tidak bergerak. Dikatakan demikian karena benda yang dijaminkan adalah benda yang berdasarkan sifatnya tidak bergerak dan tidak dapat dipindah-pindahkan. Pengikatan terhadap jaminan dalam bentuk benda bergerak adalah berupa hak tanggungan.

3. Penggolongan jaminan berdasarkan terjadinya, terdiri dari:

a. Jaminan yang lahir karena undang-undang, artinya jaminan yang keberadaannya ditunjuk oleh undang-undang, tanpa adanya perjanjian dari para pihak. Contohnya adalah jaminan yang diatur dalam Pasal $1131 \mathrm{KUH}$ Perdata, seperti jaminan umum, hak privelege dan hak retentie.

b. Jaminan yang lahir karena perjanjian, adalah jaminan yang terjadi karena adanya perjanjian antara para pihak sebelumnya, seperti gadai (pand), fidusia dan hak tanggungan.

Lembaga jaminan ini sangat diperlukan bagi pelaku-pelaku bisnis, karena dalam melaksanakan bisnis tentunya memerlukan dana dengan jumlah besar yang sebagian disalurkan oleh bank kepada masyarakat dalam bentuk pemberian kredit. 
Pemberian kredit selalu mengandung risiko, sehingga diperlukan suatu jaminan kredit.

Sebagaimana yang disebutkan di atas bahwa salah satu syarat dalam perjanjian jaminan adalah tidak menghambat usaha yang memberikan jaminan (debitor) dan jaminan yang paling sesuai disini adalah jaminan fidusia. Alasannya bahwa benda yang dijadikan jaminan (objek jaminan) tetap berada dalam kekuasaan debitur walaupun hak atas benda tersebut untuk sementara telah berpindah kepada kreditor. Berdasarkan perkembangan dalam sejarahnya, fidusia berawal dari suatu perjanjian yang hanya didasarkan pada kepercayaan, tetapi lama kelamaan dalam praktiknya diperlukan suatu kepastian hukum yang dapat melindungi kepentingan para pihak, yang pada saat ini telah diatur dalam UU No. 42 Tahun 1999. Fidusia merupakan suatu jaminan yang didasarkan pada adanya perjanjian pokok, jadi merupakan perjanjian ikutan dari suatu perjanjian pokok tertentu misalnya perjanjian kredit/hutang piutang yang jaminannya adalah barang bergerak.

Sebagaimana yang telah diuraikan sebelumnya, bahwa fidusia merupakan bagian dari lapangan hukum kebendaan sebagaimana yang dimaksud dalam Buku II KUH Perdata, tetapi ketentuan khusus tentang fidusia ini tidak ditemui pengaturannya dalam KUH Perdata, melainkan diatur tersendiri dalam UU No. 42 Tahun 1999. Berhubung bahwa fidusia juga merupakan bagian dari hukum benda, maka asas-asas hukum yang berlaku umum dalam Buku II KUH Perdata juga berlaku bagi fidusia. Oleh sebab itu, sudah sewajarnya asas hukum yang terdapat dalam UU No. 42 Tahun1999, diselaraskan dan menganut asas-asas hukum kebendaan yang terdapat dalam Buku II KUH Perdata.

Ada beberapa aturan terkait dengan asas hukum kebendaan yang terdapat dalam UU No. 42 Tahun 1999, yang masih perlu dikoreksi karena dalam implementasinya dapat menimbulkan persoalan hukum yang baru di bidang hukum jaminan, yaitu:

1. Ketentuan Pasal 11 ayat (1) dan Pasal 12 ayat (1) UU No. 42 Tahun 1999.

Dalam Pasal 11 ayat (1) dinyatakan bahwa benda yang dibebani jaminan fidusia wajib didaftarkan. Selanjutnya dalam Pasal 12 ayat (1) 
dinyatakan bahwa pendaftaran jaminan fidusia sebagaimana dimaksud dalam Pasal 11 ayat (1) dilakukan pada Kantor Pendaftaran Fidusia.

Berdasarkan kedua ketentuan tersebut di atas dan sesuai dengan asas publisitas, maka pendaftaran jaminan fidusia bertujuan agar dapat ketahui bahwa sesuatu benda telah dijadikan jaminan bagi pelunasan hutang karena adanya perjanjian kredit antara debitor dan kreditor. Hal yang perlu dikoreksi disini adalah tentang objek yang didaftarkan.

Berdasarkan ketentuan pada Pasal 11 ayat (1) dan Pasal 12 ayat (1) tersebut, yang didaftarkan adalah "benda" yang dijadikan (objek) jaminan fidusia. Selanjutnya berdasarkan Pasal 1 ayat (2), bahwa jaminan fidusia adalah hak atas jaminan atas benda bergerak baik yang berwujud maupun yang tidak berwujud dan benda tidak bergerak khususnya bangunan yang tidak dapat dibebani hak tanggungan sebagaimana dimaksud dalam UU No. 4 Tahun 1996 yang tetap berada dalam penguasaan pemberi fidusia, sebagai agunan bagi pelunasan uang tertentu, yang memberikan kedudukan yang diutamakan kepada penerima fidusia terhadap kreditor lainnya. Sedangkan berdasarkan Pasal 1 ayat (4), disebutkan bahwa benda adalah segala sesuatu yang dapat dimiliki dan dialihkan, baik yang berwujud maupun yang tidak berwujud, yang terdaftar maupun yang tidak terdaftar, yang bergerak maupun yang tidak bergerak yang tidak dapat dibebani hak tanggungan atau hipotek.

Selanjutnya dapat pula diperhatikan ketentuan yang terdapat dalam Pasal 4, bahwa jaminan fidusia merupakan perjanjian ikutan dari suatu perjanjian pokok bukan kewajiban bagi para pihak untuk memenuhi suatu prestasi. Kemudian dalam Pasal 5 ayat (1), ditentukan pula bahwa pembebanan benda dengan jaminan fidusia dibuat dengan akta notaris dalam Bahasa Indonesia dan merupakan akta jaminan fidusia.

Memperhatikan pengertian benda yang dapat dijadikan jaminan fidusia, kemudian dikaitkan dengan pengertian jaminan fidusia merupakan perjanjian ikutan yang tertuang dalam akta jaminan fidusia sebagai agunan bagi pelunasan uang tertentu, maka jaminan fidusia menjadi preferen bagi kreditor jika jaminan fidusia didaftarkan, karena kedudukan preferen dijamin 
setelah adanya pendaftaran jaminan fidusia. Sehubungan hal ini, maka yang seharusnya didaftarkan bukanlah benda yang dijadikan objek jaminan fidusia, tetapi justru jaminan fidusianyalah yang perlu didaftarkan. Sesuai pula dengan pengertian benda pada Pasal 1 ayat (4), bahwa benda dalam jaminan fidusia dapat benda yang "terdaftar" maupun "tidak terdaftar".

Jaminan fidusia merupakan perjanjian (accesoir), maka lazimya perjanjian memuat klausula-klausula perjanjian. Oleh karena itu, dalam akta jaminan fidusia tentulah diatur mengenai benda yang menjadi jaminan fidusia. Dengan demikian, akta jaminan fidusia ini perlu didaftarkan untuk menjamin hak kreditur yang preferen. Secara keseluruhan, jaminan fidusia cakupannya lebih luas, artinya mencakup benda yang menjadi jaminan fidusia yang sudah tertuang dalam akta jaminan fidusia tersebut.

Dengan didaftarkannya jaminan fidusia maka asas publisitas terpenuhi sekaligus merupakan jaminan kepastian terhadap kreditor lainnya mengenai benda yang telah dibebani dengan jaminan fidusia. Jaminan fidusia lahir pada tanggal yang sama dengan tanggal dicatatnya jaminan fidusia dalam buku pendaftaran fidusia.

Pendaftaran jaminan fidusia akan memberikan informasi data-data baik mengenai ikatan jaminannya, maupun bendanya, karena dalam suatu pendaftaran fidusia semua hal tersebut dicatat dengan teliti oleh Kantor Pendaftaran Fidusia, sejalan dengan ketentuan dalam Pasal 13 Ayat (2) yang semuanya bertujuan untuk tercapainya kepastian hukum, karena dengan pendaftaran tersebut akan diketahui:
a. Siapa para pihaknya.
b. Perikatan pokok apa yang dijamin.
c. Besarnya utang.
d. Besarnya beban jaminan
e. Data kepemilikan atas benda yang dijaminkan.
f. Klausula-klausulanya. 
Pada saat dilakukan pendaftaran, maka semua perihal yang terkait dengan jaminan fidusia dicatat dengan rinci. Dengan adanya pencatatan ini, maka akan diperoleh manfaat sebagai berikut:

a. Pemilik mempunyai bukti kepemilikan yang relatif pasti.

b. Kreditor punya bukti hak jaminan yang pasti, sertifikat jaminan fidusia memberikan alasan hak bagi kreditor.

c. Pihak ketiga tidak dapat lagi mengatakan bahwa ia tidak tahu siapa pemilik benda itu, hal ini berkenaan dengan adanya asas publisitas dalam pembebanan benda jaminan.

d. Pihak ketiga tidak lagi mengemukakan bahwa ia tidak tahu barang benda tertentu, milik orang tertentu, sedang memikul beban jaminan untuk kreditor tertentu.

Berdasarkan uraian di atas, dapatlah dikatakan bahwa ketentuan yang terdapat dalam Pasal 11 ayat (1) adalah kurang tepat, karena yang didaftarkan pada Kantor Pendaftaran Fidusia, bukanlah terbatas pada "benda" yang dijadikan jaminan fidusia, melainkan semua hal-hal yang terkait dengan jaminan fidusia itu sendiri.

2. Ketentuan Pasal 15 ayat (2) dan ayat (3) serta Pasal 29 Ayat (1) huruf a, b, dan c UU No. 42 Tahun 1999.

Dalam Pasal 15 ayat (2) dinyatakan bahwa sertifikat jaminan fidusia sebagaimana dimaksud dalam ayat (1) mempunyai kekuatan eksekutorial yang setara dengan putusan pengadilan yang telah memperoleh kekuatan hukum tetap. Selanjutnya dalam ayat (3) dinyatakan bahwa apabila debitor cidera janji, penerima fidusia mempunyai hak menjual benda yang menjadi objek jaminan fidusia atas kekuasaannya sendiri.

Terkait dengan ketentuan Pasal 15 ayat (1) dan ayat (3), maka berdasarkan Pasal 29 ayat (1) bahwa apabila debitor atau pemberi fidusia cidera janji, eksekusi terhadap benda yang menjadi objek jaminan fidusia dapat dilakukan dengan cara:

a. Pelaksanaan title eksekutorial sebagaimana dimaksud dalam Pasal 15 ayat (2) oleh penerima fidusia. 
b. Penjualan benda yang menjadi objek jaminan fidusia atas kekuasaan penerima fidusia sendiri melalui pelelangan umum serta mengambil pelunasan piutangnya dari hasil penjualan.

c. Penjualan di bawah tangan yang dilakukan berdasarkan kesepakatan pemberi dan penerima fidusia jika dengan cara demikian dapat diperoleh harga tertinggi yang menguntungkan para pihak.

Memperhatikan ketentuan-ketentuan ini, maka dapat dikatakan bahwa UU No. 42 Tahun 1999 mengikuti cara eksekusi barang jaminan yang digunakan oleh UU No. 4 Tahun 1996, yaitu memberikan alternatif eksekusi barang jaminan fidusia melalui penjualan secara lelang dan penjualan di bawah tangan (Bachtiar Sibarani, 2000: 21). Eksekusi jaminan fidusia menurut UU No. 42 Tahun 1999 sebenarnya hanya mengenal 2 (dua) cara eksekusi, meskipun perumusannya seakan-akan menganut 3 (tiga) cara. Kedua cara tersebut yaitu:

a. Melaksanakan titel eksekusi dengan menjual objek jaminan fidusia melalui lelang atas kekuasaan penerima fidusia sendiri dengan menggunakan parate eksekusi. Arti parate eksekusi menurut kamus hukum, ialah pelaksanaan yang langsung tanpa melewati proses (pengadilan atau hakim). Arti parate eksekusi yang diberikan doktrin adalah kewenangan untuk menjual atas kekuasaan sendiri apa yang menjadi haknya, dalam arti tanpa perantaraan hakim, yang ditujukan atas sesuatu barang jaminan, tanpa harus minta fiat dari ketua pengadilan (Ari S. Hutagalung, 2008: 162). Di sini terlihat inkonsistensi dari pasal-pasal tersebut di atas, pengertian parate eksekusi dalam UU No. 42 Tahun 1999 lebih merupakan kewenangan yang diberikan oleh undang-undang atau oleh putusan pengadilan oleh salah satu pihak untuk melaksanakan sendiri secara paksa isi perjanjian atau putusan hakim manakala pihak yang lainnya cidera janji. Pasal 15 ayat (2) dan (3) dan Pasal 29 ayat (1) huruf a dinyatakan bahwa sertifikat jaminan fidusia memiliki title eksekusi yang memiliki kekuatan hukum tetap yang setara dengan putusan pengadilan. Pelaksanaan title eksekusi ini tidak memerlukan putusan ketua pengadilan negeri untuk 
pelaksanaannya, hal ini untuk memudahkan dalam eksekusi barang yang dijaminkan secara fidusia, walaupun dalam praktiknya, eksekusi barang jaminan fidusia tidak mudah dilakukan, karena barang yang menjadi jaminan fidusia dikuasai debitor. Diperlukan tindakan pengambilalihan penguasaan terlebih dahulu karena pada umumnya barang jaminan fidusia adalah barang bergerak yang penguasaannya masih berada di tangan debitor. Berbeda misalnya dengan hak tanggungan yang hanya perlu melakukan tindakan pengosongan terlebih dahulu untuk mengeksekusi. Selanjutnya dapat diperhatikan Pasal 29 ayat (1) huruf b yang merumuskan bahwa penjualan benda yang menjadi objek jaminan fidusia atas kekuasaan penerima fidusia sendiri melalui pelelangan umum. Penjelasan Pasal 15 ayat (3) menyatakan bahwa dalam undang-undang ini dipandang perlu diatur secara khusus tentang eksekusi jaminan fidusia melalui lembaga eksekusi. Jika debitor cidera janji, maka pemegang jaminan fidusia dapat melaksanakan janji tersebut dengan menjual lelang atas kekuasaan sendiri (parate eksekusi). Pemahaman dari penjelasan Pasal 15 ayat (3) terhadap lembaga parate eksekusi, menunjukkan kehendak pembentuk undang-undang melalui penafsiran otentik untuk mengatur lembaga parate eksekusi, maksudnya pengaturan lembaga parate eksekusi masuk dalam ranah Hukum Acara Perdata, karena eksekusi barang jaminan fidusia meniru eksekusi hak tanggungan, maka kasus yang dihadapi sama dengan inkonsistensi Pasal 6 dan Penjelasan Pasal 9 UU No. 4 Tahun 1996. Ada unsur yang sama dalam eksekusi hak tanggungan dengan eksekusi jaminan fidusia, yaitu terkait dengan:

1) Debitor cidera janji.

2) Kreditur penerima jaminan mempunyai hak menjual objek jaminan atas kekuasaan sendiri.

3) Syarat penjualan pelelangan umum.

4) Hak kreditur mengambil pelunasan piutangnya dari hasil penjualan.

Sebelum berlakunya UU No. 42 Tahun 1999, eksekusi barang bergerak yang diikat dengan fidusia pada umumya tidak melalui lelang tetapi 
dengan mengefektifkan kuitansi kosong yang sebelumnya telah ditandatangani oleh pemilik barang jaminan atau debitor(Bachtiar Sibarani, 2000: 21). Pada waktu yang lalu, tidak ada eksekusi jaminan fidusia yang melalui pelelangan umum. Oleh karena itu, sudah seharusnya eksekusi barang jaminan fidusia yang telah mempunyai titel eksekusi tidak melalui pelelangan umum, sebab pelelangan umum tetap memerlukan suatu keputusan Ketua Pengadilan bagi pelaksanaannya. Dengan demikian, eksekusi benda jaminan fidusia berarti dapat menyimpang dari ketentuan titel eksekusi yang tidak memerlukan campur tangan pengadilan atau hakim.

b. Menjual objek jaminan fidusia secara di bawah tangan atas dasar kesepakatan pemberi dan penerima jaminan fidusia. Seperti halnya dalam UU No. 4 Tahun 1996, maka dalam jaminan fidusia ini penjualan di bawah tangan objek fidusia juga mengandung beberapa persyaratan yang relatif berat untuk dilaksanakan.

3. Ketentuan Pasal 17 dan Pasal 28 UU No. 42 Tahun 1992.

Dalam Pasal 17 ditentukan bahwa pemberi fidusia dilarang melakukan fidusia ulang terhadap benda yang menjadi objek jaminan fidusia yang sudah terdaftar. Selanjtunya dalam Penjelasan Pasal 17 dikatakan bahwa fidusia ulang oleh pemberi fidusia, baik debitor maupun penjamin pihak ketiga, tidak dimungkinkan atas benda yang menjadi objek jaminan fidusia karena hak kepemilikan atas benda tersebut telah beralih kepada penerima fidusia.

Lebih lanjut dalam Pasal 28 ditentukan pula bahwa apabila atas benda yang sama menjadi objek jaminan fidusia lebih dari satu perjanjian jaminan fidusia, maka hak yang didahulukan sebagaimana dimaksud dalam Pasal 27, diberikan kepada pihak yang lebih dahulu mendaftarkannya pada Kantor Pendaftaran Fidusia.

Berdasarkan Pasal 28 di atas, secara logika dapat dikatakan bahwa objek yang menjadi jaminan fidusia dapat didaftarkan untuk kedua kalinya. Padahal hal ini bertentangan dengan Pasal 17 yang melarang atas benda yang sama yang menjadi objek jaminan fidusia lebih dari satu perjanjian. Dalam 
praktik, banyak terjadi fidusia ulang terhadap benda yang menjadi jaminan fidusia. Akibat kondisi ini maka ketentuan Pasal 17 menjadi bias, karena dalam praktiknya fidusia ulang dapat dilakukan terhadap benda yang menjadi jaminan fidusia tergantung kepada nilai kredit dan jaminan yang ditanggung oleh jaminan fidusia. Misalkan nilai benda yang menjadi jaminan fidusia Rp 100.000.000 (seratus juta rupiah), namun debitor mengajukan kredit dengan jaminan fidusia Rp 25.000.000 (dua puluh lima juta rupiah). Sisa nilai benda ini pada umumnya dapat di fidusiakan ulang untuk memenuhi nilai tersebut. Namun demikian, sesuai ketentuan Pasal 28, maka kreditur yang diutamakan apabila perjanjian fidusia lebih dari satu adalah perjanjian fidusia yang jaminannya didaftar terlebih dahulu di Kantor Pendaftaran Fidusia.

\section{E. Penutup}

Berdasarkan analisis yang telah diuraikan pada Bab III, dapat disimpulkan bahwa asas-asas hukum yang terdapat dalam lapangan hukum kebendaan sebagaimana yang diatur dalam Buku II KUH Perdata tentunya berlaku pula terhadap perjanjian jaminan fidusia. Namun dalam penerapanan asas hukum itu sendiri masih terdapat inkonsistensi UU No. 42 Tahun 1999, terutama terkait dengan asas publisitas yang terkait dengan aturan pada Pasal 11 ayat (1). Semestinya dalam ketentuan yang terdapat pada Pasal 11 ayat (1) menentukan bahwa pendaftaran bukanlah terhadap bendanya melainkan terhadap jaminan fidusia.

Selain itu, walaupun dalam jaminan fidusia jika debitor cedera janji dapat memberikan kewenangan secara langsung kepada kreditor untuk melakukan eksekusi langsung, namun dalam praktiknya tidak mungkin dapat dilaksanakan. Alasannya bahwa eksekusi langsung (parate eksekusi) juga harus dilakukan melalui pelelangan umum, berarti tetap harus didasarkan pada putusan pengadilan terlebih dahulu.

Inkonsistensi lainnya juga terkait dengan fidusia ulang terhadap benda yang sudah dijadikan jaminan fidusia, yang berdasarkan Pasal 17 UU No. 42 Tahun 1999 tidak dibolehkan. Namun demikian jika didasarkan pada Pasal 28 UU 
No. 42 Tahun 1999, sebenarnya masih dimungkinkan untuk melakukan fidusia kembali terhadap objek (benda) yang sebelumnya telah dijadikan objek jaminan fidusia.

UU No. 42 Tahun 1999 masih perlu direvisi kembali, terutama terkait dengan pendaftaran jaminan fidusia, eksekusi fidusia dan kemungkinkan boleh atau tidaknya objek (benda) yang sudah dijadikan jaminan fidusia, kembali dijadikan jaminan fidusia terhadap perjanjian pokok lainnya. 


\section{DAFTAR PUSTAKA}

\section{Buku:}

Gunawan Widjaya dan Ahmad Yani. 2001. Jaminan Fidusia. Jakarta: RajaGrafindo Persada.

Munir Fuady. 2000. Jaminan Fidusia. Bandung: Citra Aditya Bakti.

Purwahid Patrik dan Kashadi. 2001. Hukum Jaminan, Revisi dengan UUHT. Semarang: Fakultas Hukum-Undip.

Satrio, J. 2002. Hukum Jaminan Hak Jaminan Kebendaan Fidusia. Bandung: Citra Aditya Bakti.

Sri Soedewi Masjchoen Sofwan. 1997. Hukum Jaminan di Indonesia: Pokokpokok Hukum Jaminan dan Jaminan Perorangan. Jakarta: Badan Pembinaan Hukum Nasional.

\section{Jurnal:}

Hutagalung, Ari S. 2008. "Praktek Pembebanan dan Pelaksanaan Eksekusi Hak Tanggungan di Indonesia”. Jurnal Hukum dan Pembangunan. Tahun ke38 No. 2. April-Juni. Jakarta: Badan Penerbit FH-UI.

Sibarani, Bachtiar. 2000. "Aspek Hukum Eksekusi Jaminan Fidusia”, Jurnal Hukum Bisnis. Vol. 11. Jakarta: Yayasan Pengembangan Hukum Bisnis.

\section{Peraturan Perundang-undangan:}

Republik Indonesia, Undang-undang Nomor 4 Tahun 1996 tentang Hak Tanggungan.

Republik Indonesia, Undang-undang Nomor 42 Tahun 1999 tentang Jaminan Fidusia.

\section{Internet:}

Auditmepost.blogspot.com. "Sekilas tentang Fidusia dan Jaminan Fidusia", http://auditme-post.blogspot.com. Diakses tanggal 2 Juli 2017.

Kuliahade's Blog. "Hukum Perdata: Asas-asas Umum Hak Kebendaan”. http:// kuliahade.wordpress.com. Diakses tanggal 2 Juli 2017. 


\section{BIODATA PENULIS}

$\begin{array}{ll}\text { Nama } & : \text { Vivi Lia Falini Tanjung, S.H. } \\ \text { Pekerjaan } & : \text { Wiraswasta } \\ \text { Jabatan } & :- \\ \text { Nomor HP } & : 081263008181 \\ \text { E-mail } & : \text { tanjungn10@ gmail.com } \\ \text { Alamat } & : \text { Jl. Sei. Belutu No. 9, Kecamatan Medan Baru, Kota Medan, } \\ & 20153\end{array}$

